\title{
Main favorable factorscreatee oligocene formation become a petroleum prospect in south-east area, Cuu Long basin
}

- Tran Nhu Huy

Faculty of Geology and Petroleum Engineering, Ho Chi Minh city University of Technology, VNU-HCMC \& PVEP-POC

- Tran Van Xuan

- Nguyen Xuan Kha

- Thai Ba Ngoc

- Truong Quoc Thanh

- Ho Nguyen Tri Man

- Nguyen Dinh Chuc

Faculty of Geology and Petroleum Engineering, Ho Chi Minh city University of Technology, VNU-HCMC

- Tran Duc Lan

Vietsovpetro

(Manuscript Received on August 10 $0^{\text {th }}$,2015; Manuscript Revised on October 20 $0^{\text {th }}$, 2015)

\begin{abstract}
The previous researchs almost demonstrated the reservoir in Lower Oligocene sandstone has complicated distribution, probably low porosity and permeability, no nature flow are seen by wells. Based on recent study results of depositional environment of $E$ Oligocene sedimentary in Cuu Long basin and $E$ sand distribution in blocks $01 / 10$ \& $02 / 10$, block 09-2/09, block 09-2/10 and block 16-2 area, the paper determines depositional facies according to petrophysic and geophysic data. From Chrono-stratigraphy priciple, as well as interpretation and intergration of seismic data,

results, petrophysic data, well test data, the paper forcuses on create correlation lines between wells and seismic line for confirming Oligocene E distribution in Cuu Long basin, buildup the gross mapping for depositional environment in sub-sequence Oligocene E upper and $E$ lower and mapping of seismic attributes for sub-sequence Oligocene $E$ upper and $E$ lower.At last successfully predict the sand distribution in Oligocene E upper and E lower sub-sequence in research area and hence determine the stratigraphic traps in Oligocene formation of South-East area Cuulong basin.
\end{abstract} well data, well log data, core \& sample analysis

Key words: Lower Oligocene sandstone, low Pore-Perm, seismic attributes, petrophysiccurves, geophysiccharacteristics, prediction, distribution. 


\section{GENERAL INTRODUCTION}

The main target in Cuu Long basin is PreTertiary fractured granite basement, Lower Miocene sandstone and also Lower Oligocene sandstones. Previously, the fractured basement and Lower Miocene sandstone reservoirs (the traditional targets) are being depleted so exploration is focused on Lower Oligocene sandstone. However, this reservoir has complicated distribution, probably low porosity. Tight sandstone with porosity from 10 to $15 \%$, permeability lower than $10 \mathrm{mD}$, no nature flow are seen by wells. But in some marginal areas such as North East Bach Ho, Su TuNau and KinhNguTrang, there are several fair porosity and permeability reservoirs, 1,000 to more than 3,000 BOPD natural flow [1]. Recent wells in KinhNguTrang, KinhNguTrang Nam area as well as Thang Long wells of Lam Son JOC also show that sand bodies in Oligocene $\mathrm{E}$ are the main reservoirs. From these wells, bituminous shale layers can be firmed as the seal of these sand bodies with thickness of 15 to 70mTVD.

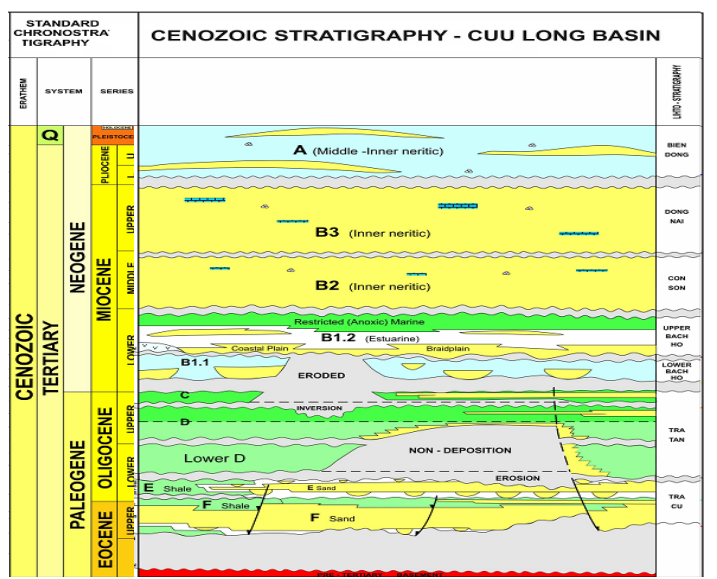

Figure a. A model of Chrono-stratigraphy of Cuu Long basin

Generally, in Cuu Long basin, the "E/F?" sequence underlies the organic rich dark yellowish brown shaly, claystone and is
In Cuu Long basin, E Oligocene sediment was buried in big depth and large varied from the area to area. In the top of the positive structures, E Oligocene sediment is moderate thin, which distributed in depth of 3,000 to $4,000 \mathrm{mss}$. Meanwhile, in the flanks of these structures, this sedimentary is distribute in depth of 4,000 to $5,000 \mathrm{mss}$ and the thickness could be approach to $1,000 \mathrm{mTVD}$. Due to burry in varied depths hence E Oligocene sediment had been altered irregular and moderate complicated [2].

Up to now, there are several different subdivisions of the Oligocene sequence in other block of Cuu Long basin. It is caused by the variety of seismic characteristics in another blocks as well as lithology characteristics [4].

The stratigraphy of Cuu long basin is summarized hereafter (fig.a):

- Pre-Tertiary Basement

- Late Oligocene

Lower Tra Tan formation - E/F (?) sequence (thickness: $0-1,500 \mathrm{~m}$ )

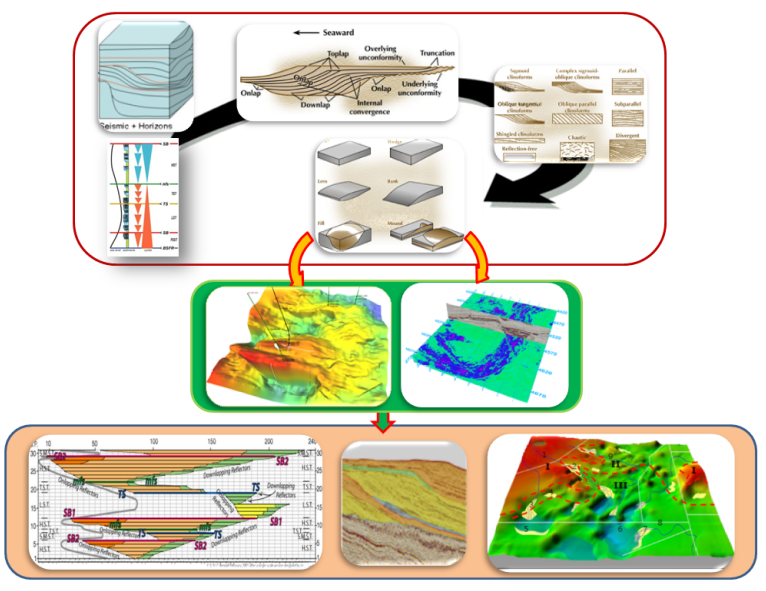

Figure.b. The seismic stratigraphic workflow

distinguished by coarse grained and breccias/conglomerate of the sandstone with granitic fragments and overlies the weathered 
basement. It is generally thin or absent in most parts and only present on the flank of the structures. Main characters of log curves of $\mathrm{E}$ sequence are relatively high density and resistivity, meanwhile DT is low.

This sequence is determined to be both excellent source and good reservoir. Depositional environment was alluvial-fluvial lacustrine conditions.

Middle Tra Tan formation $-D$ sequence (Thickness: 300-over 2,000 m).

Upper Tra Tan formation - C sequence (Thickness: $0-250 \mathrm{~m}$ )

- Early Miocene : Bach Ho formation - BI sequence (thickness: $300-1,250 \mathrm{~m}$ )

- Middle Miocene: Con Son formation BII sequence (thickness: 250 - 900m)

- Late Miocene:Dong Naiformation - BIII sequence (thickness: $500-750 \mathrm{~m}$ )

- Pliocene-Quaternary:Bien Dong formation - A sequence (thickness: $400-700 \mathrm{~m}$ ).

\section{Methodology}

Based on Chrono-stratigraphyprinciple (fig.b), seismic data, well data, well log data, core \& sample analysis results, petrophysic data, well test data will be intepred and intergrated(petrophysiccurves, geophysiccharacteristics) inorder to modelizing the geological feature hence predict the sand distribution in Oligocene E upper and E lower sub-sequence in block 09.2, 09.3 area.

\section{New discoveries in Oligocene $E$ sequences:}

There are several fair porosity and permeability reservoirs, 1,000 to more than 3,000 BOPD natural flow (Fig. 01). Recent wells of PVEP POC in KinhNguTrang, KinhNguTrang Nam area as well as Thang Long wells of Lam Son JOC also show that sand bodies in Oligocene $\mathrm{E}$ are the main reservoirs. From these wells, bituminous shale layers can be firmed as the seal of these sand bodies with thickness of 15 to 70mTVD.

In Cuu Long basin, E Oligocene sediment was buried in big depth and large varied from the area to area. In the top of the positive structures, E Oligocene sediment is moderate thin, which distributes in the depth of 3,000 to $4,000 \mathrm{mss}$. Meanwhile, in the flanks of these structures, this sediment is distribute in depth of 4,000 to $5,000 \mathrm{mss}$ and the thickness could be approach to $1,000 \mathrm{mTVD}$. Due to burry in varied depths hence E Oligocene sediment had been altered irregular and moderate complicated (Fig. 02; 03.a, b). 


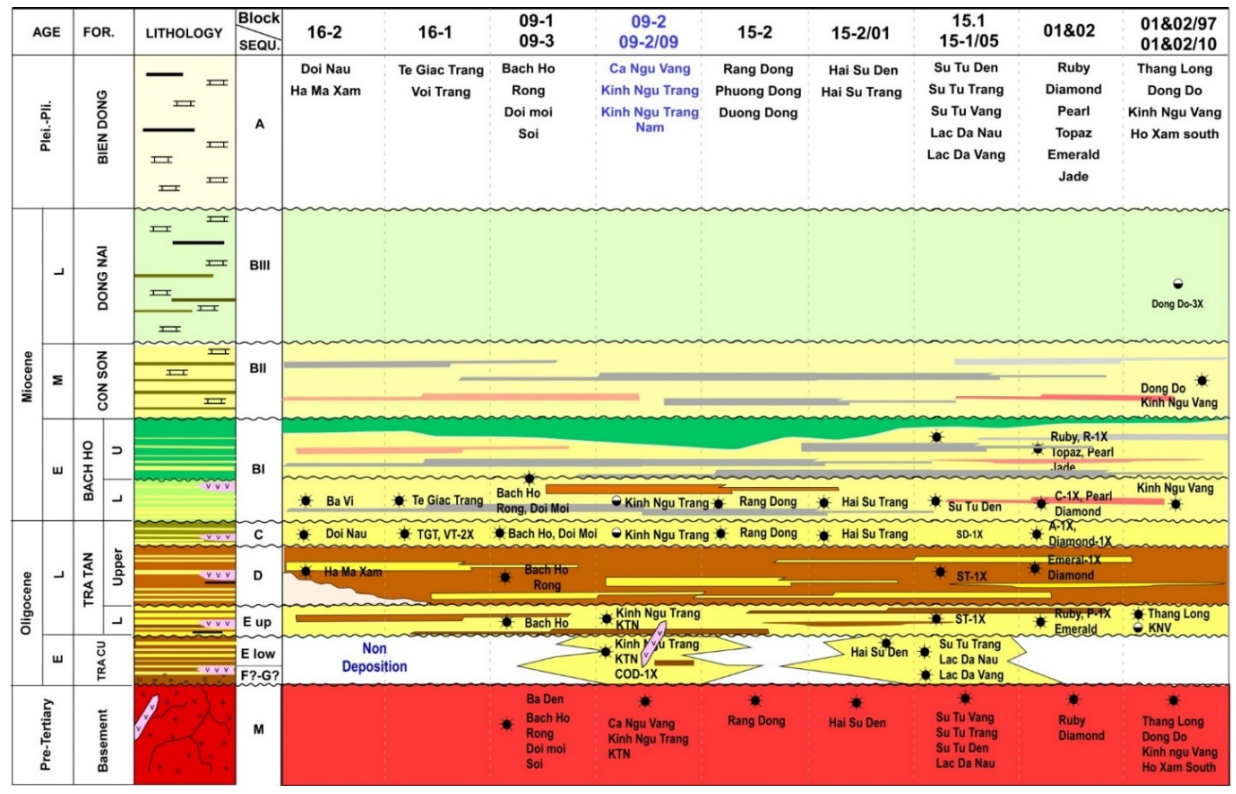

Figure 1. Oil discoveries in Cuu Long basin

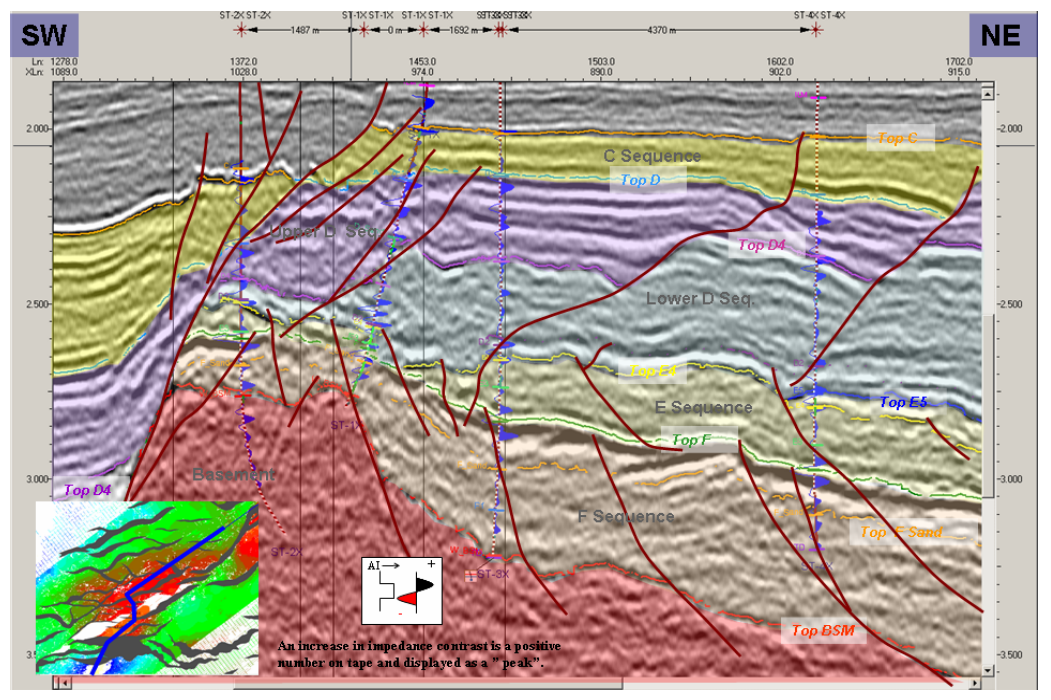

Figure 2. Seismic section through the ST, block 15.1, shows the distribution of Oligocene sediment in vertical 


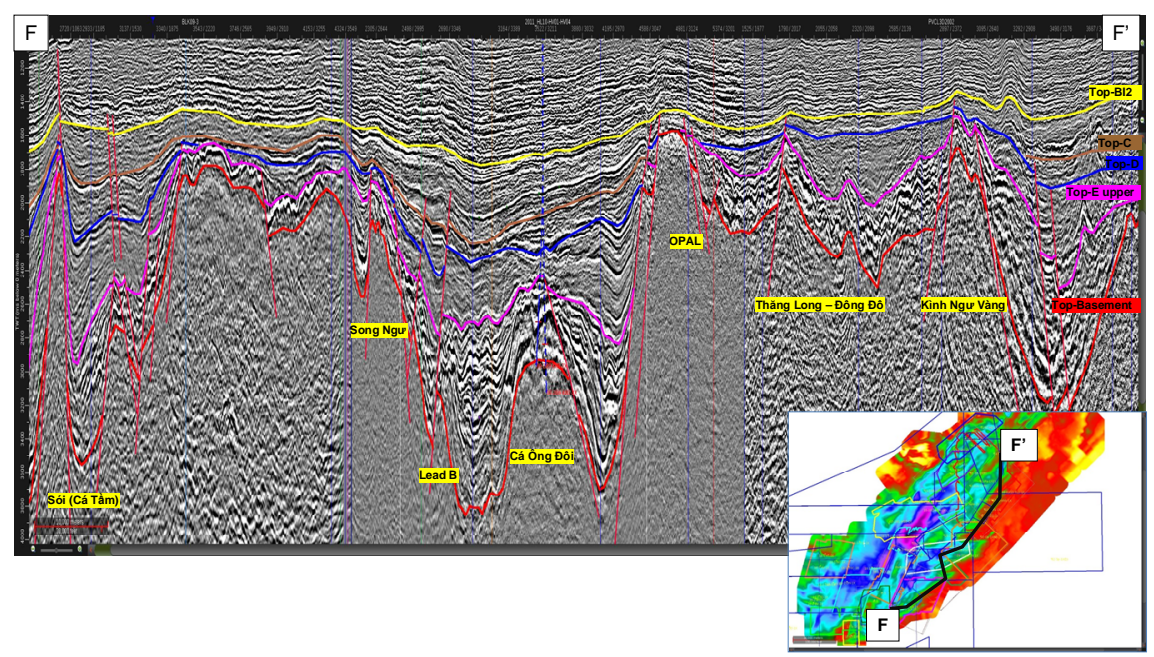

Figure 3.a. The seismic section shows E Oligocene sequence distribution in NE-Eastern part of Cuu Long basin

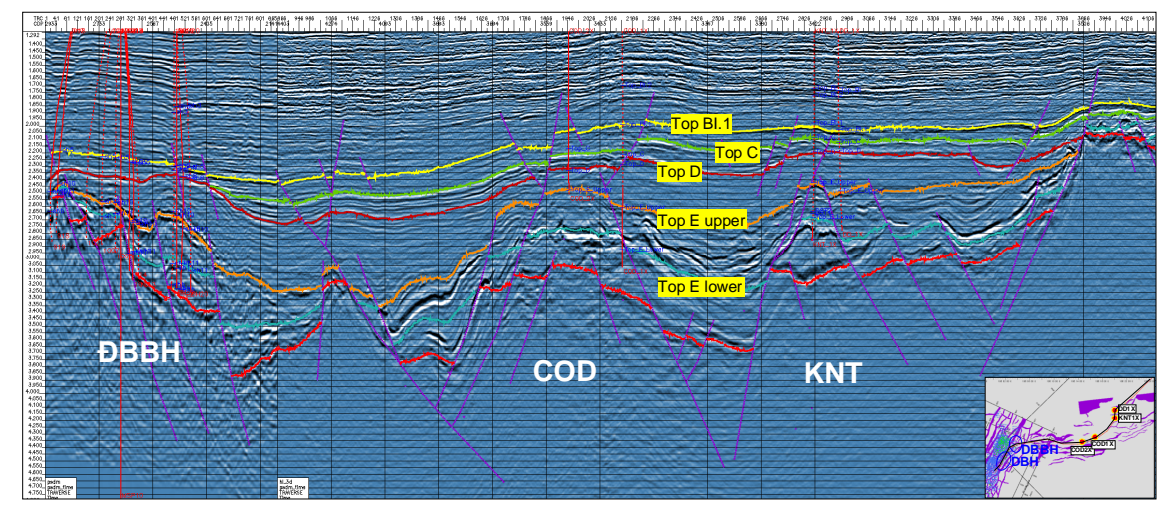

Figure 3.b. Seismic section shows the distribution of E Oligocene sequence in Southeastern part of Cuu Long basin

\section{The petroleum potential in $\mathbf{E}$ sequences:}

- By Late Oligocene time, the sedimentary source was more distal resulting in predominantly interbedded mudstones and sandstones being deposited in an environment varying from fluvial in South-West to more lacustrine in North-East of the basin. Very thick deposits of lacustrine shales filled the deep grabens in the Central and Northeast of the basin and draped over the basin horsts, setting up the hydrocarbons traps seen today. From late Early to early Late Oligocene time due to the opening of the East of Vietnam Sea, the faulting in the
Cuu Long basin was reactivated and was associated with intensive volcanic activity throughout the basin. This reactivated faulting caused tilting and erosion of the previously deposited sediments ( $E$ and $\mathrm{D}$ sequences). At the end of Oligocene time the Northern basin was compressed resulting in the inversion of Oligocene section (fig. 04)

- The source rock: In Southeastern flank, in KNT area, Bitumen shale had been encountered in E lower section. This shale has thickness variety from 15 to $60 \mathrm{~m}$, it was deposited in deep lacustrine/lake condition [4]. 
Geochemistry analysis for bitum exhibit good to excellent organic richness (TOC 11\%) and show very good to excellent hydrocarbon generation potential $(\mathrm{S} 2 \sim 63 \mathrm{Kg} / \mathrm{T})$ [4].

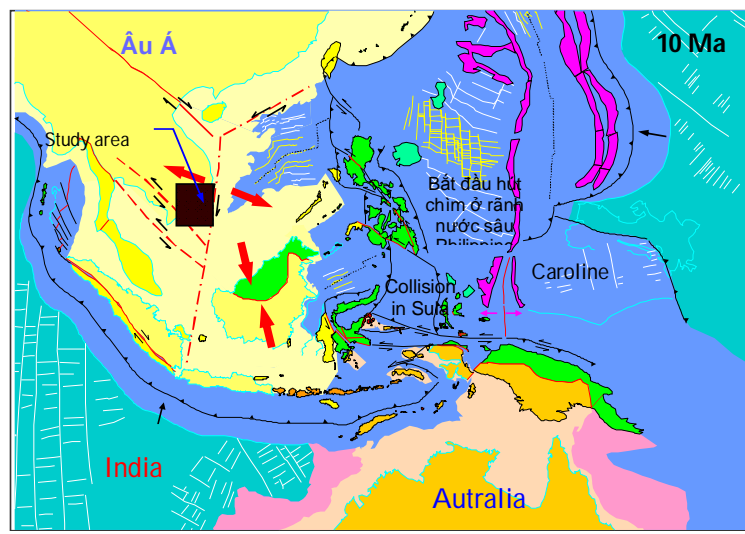

Figure 4. The Southeast Asia tectonic model at 10Ma [3]

- The trap mechanism: According to Lambiase and Morley (1999) and Olsen (1990), variations in climate, in addition to plate tectonic activities, can significantly impact synrift sedimentation. During long period of wet climate, water level in the eastern sub-basin of Cuu Long basin rose and led to the expansion of the concurring lake (Fig. 05). The result of these changes in environment was the deposition of fine-grained (shalely) sediments on top of the previously deposited coarse-grained sediments. The evidence of this point is the existence of organic-rich (>10\% TOC) Carboniferous black shale formations, discovered in recent exploration wells in this area, with thickness of tens to hundreds of meters that deposited and distributed widely across the eastern lake (Fig.6). Due to of their considerable thicknesses and extensive distributions throughout the eastern sub-basin, these shale units are not only the sources of hydrocarbons but also the regional top seals for Early Oligocene syn-rift reservoirs of the area, resolving the previous skepticisms regarding the existence of such reliable seals.

- The reservoirs: Major exploration targets of recent discoveries in East Edge of CLB are basal sandstone reservoirs that were deposited right on top and shared a similar topography with the underlying Pre-Cenozoic granitic basement. These are fluvial/alluvial deposits of near-source sediments (Fig.07). Lithologically, these basal are mainly Arkose: Feldspar-rich sandstone composed of granitic fragments with increasing proportion toward the sedimentary source. Qualities of these reservoir are fairly good at such diagenesis depth; some are even better than reservoirs deposited later (Fig.08 \&Fig.09). Porosity/permeability was well preserved partly because the Feldspars hadn't been fully weathered (Morley, 1999; San T. Ngo, 2005). Another reason was the deposition of widely distributed stiff carboniferous shale on top of these reservoirs making it not only a top seal for the underneath reservoirs but also a "stress shield" that absorb and dissipate vertical compaction.

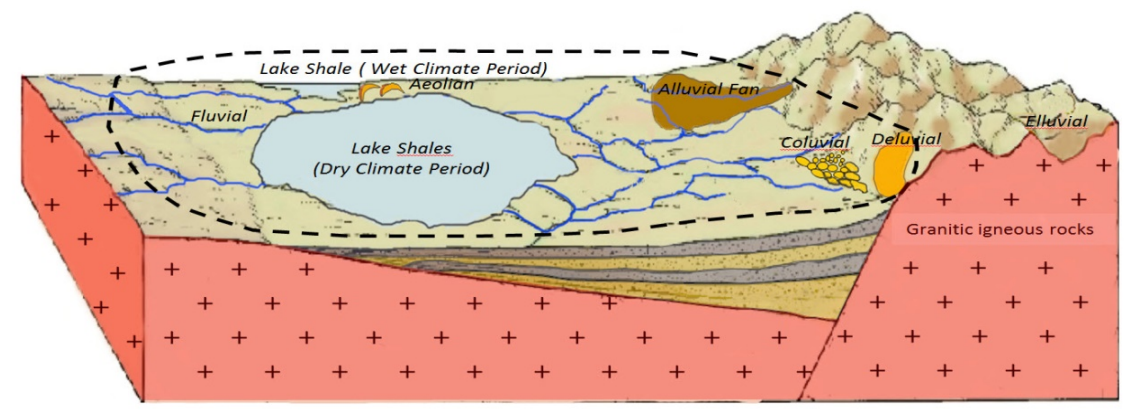

Figure 5. Illustration of Cuu Long Basin Eastern sub-basin through different climate condition 
- New research results also proved Cuu Long basin sub-basin developed through different climate condition. Cycles of alternating long periods of wet and dry climate extend or shrink the fluid covered area of the lake. During dry climate periods, the lake's water retreated and filled only the small light blue area. The uncovered area became fluvial/alluvial depositing place for near-source sediments and subsequently evolved into reservoirs.

- The Seal:On the other hand, during long periods of wet climate, the lake covered area spread out (dashed black line) facilitating lacustrine facies deposition, such as black shale to overlay the whole area making capable seals for underlying reservoirs formed during dry climate periods (Fig. 05).

\section{Internal seismic facies of sequence $\mathbf{E}$ :}

- Low frequency, high amplitude, discontinuously, nearly parallel to parallel reflection in the lower part of the uplift areas.

- Low frequency, medium to high amplitude, chaotic reflection, hummocky, weakly continuous to demonstrate alluvial fluvial depositional environment.

- Sediments deposited in these sub-garbens are dominantly alluvial fans, so-called eluvia and deluvia sediments. Alluvial fans were deposited in condition of strong currents, which flowed in multi-direction streams, slope terrains, near sediment sources. Therefore, sediments of this Formation are dominantly coarse-grained, poor sorted and angular rounded.

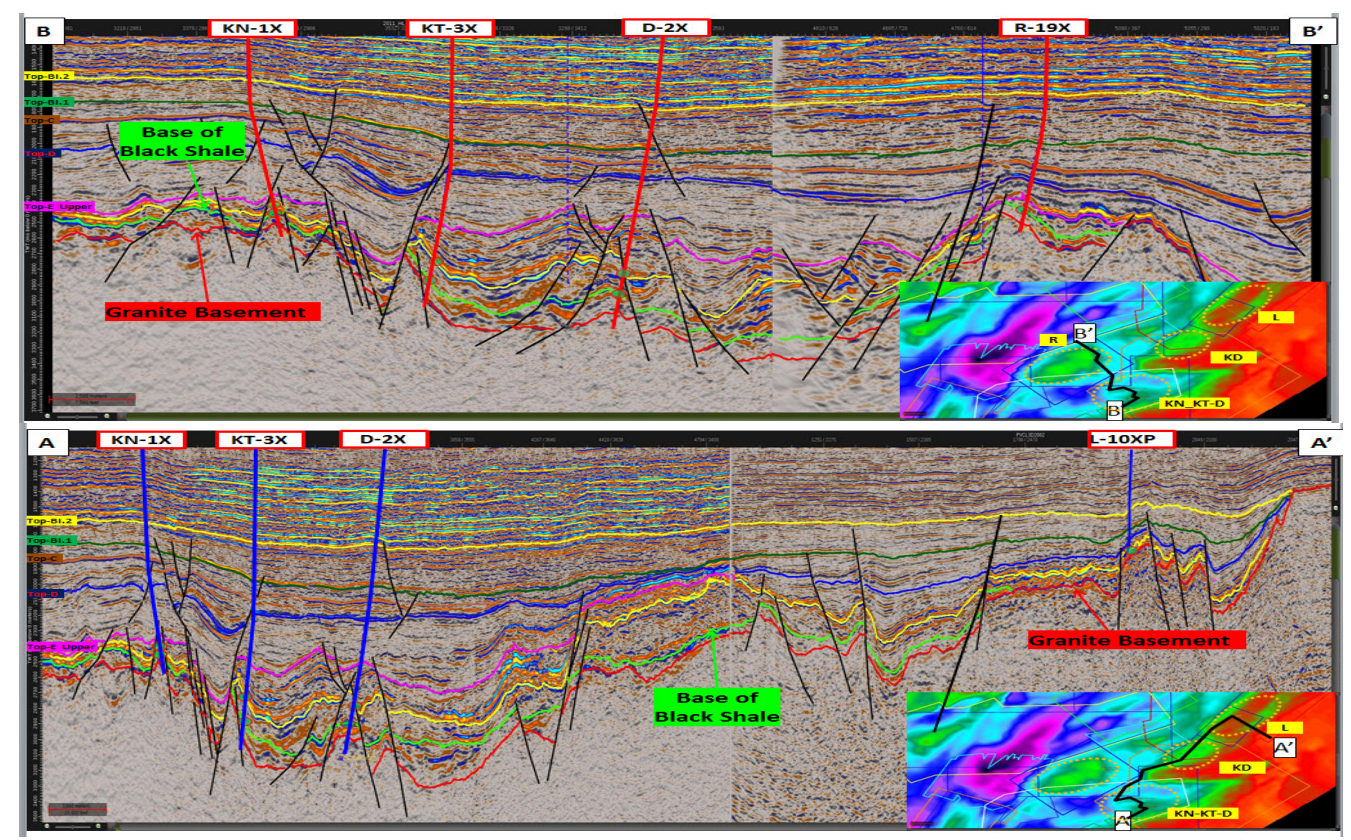

Figure 6. The AA' \& BB' seismic sections show continuity and widely distribution of the black shale unit (green horizon) in the eastern edge of Cuu long basin. 


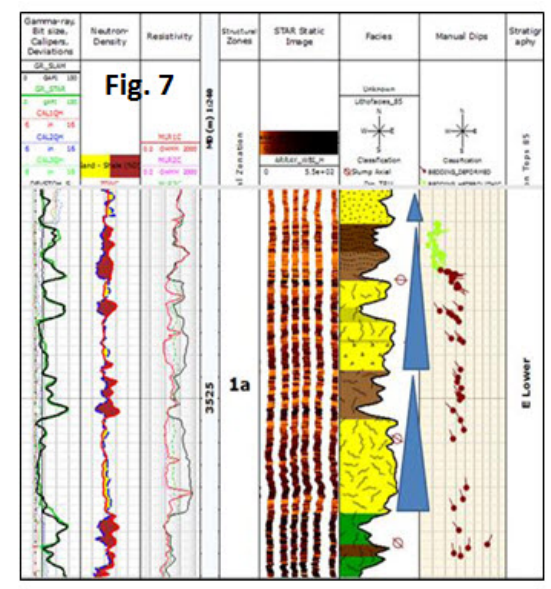

Figure 7. The depositional environment of the Basal unit was interpreted (with Image log) as prograding Alluvial Fan to Fluvial Axial Drainage System.

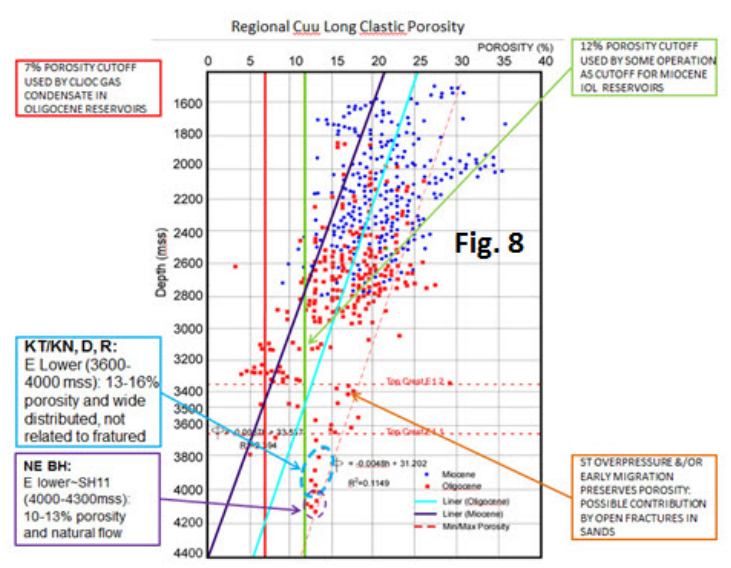

Figure 8. The porosity-depth relationship in CLB.

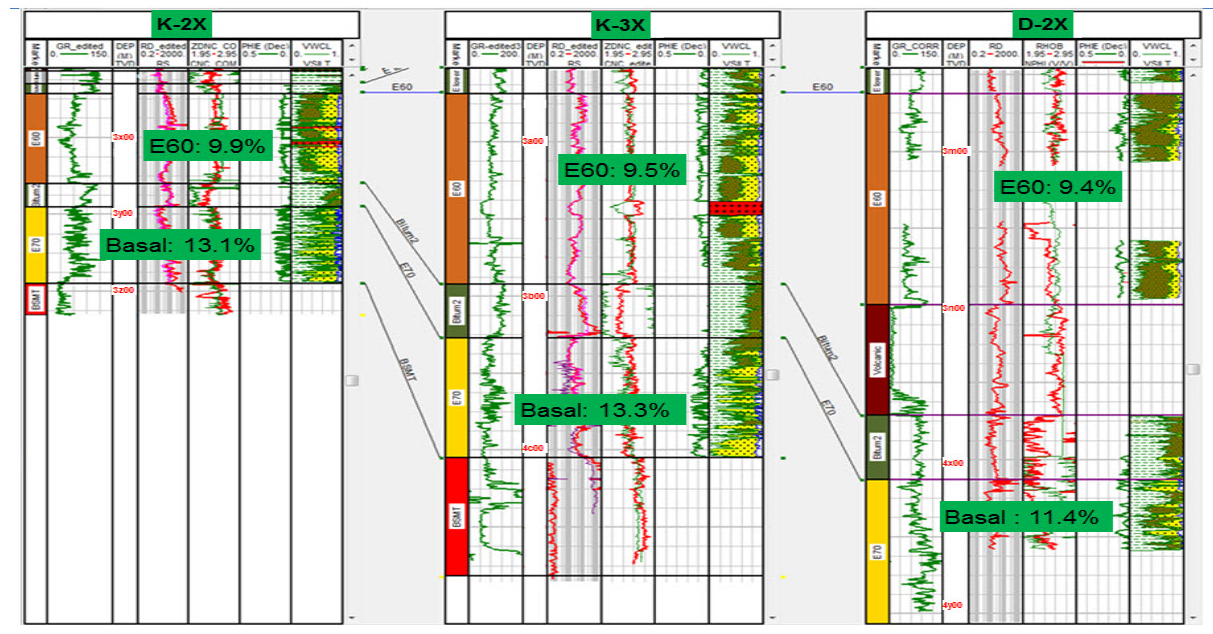

Figure 9. The depositional environment of the Basal unit was interpreted (with Image log) as prograding Alluvial Fan to Fluvial Axial Drainage System.

- At study area, in the E sequence were encountered mainly shale, silt laminate on sandstone. Porosity value was evaluated by the petrophysical analysis with core correlation. Base on the petrophysical analysis results the reservoir thickness which was distribution in the study area varies from tens to hundreds meters. In the $\mathrm{E}$ sequence exist the bitumineous shale with the thickness around $20-70$ meters as role as overburden gaining, that is possibility reason of porosity preserve in the $\mathrm{E}$ sequence. 
- Similar to Bach Ho North - East; Su TuNau; Diamond fields, in the study area the preserve porosity is moderately good, effective porosity in E sequence varies from 11 to $15 \%$, up to $18 \%$ at some wells. Base on the core and petrophysical analysis results the relationships of porosity versus depth ware conducted as figures 10, 11 bellows.

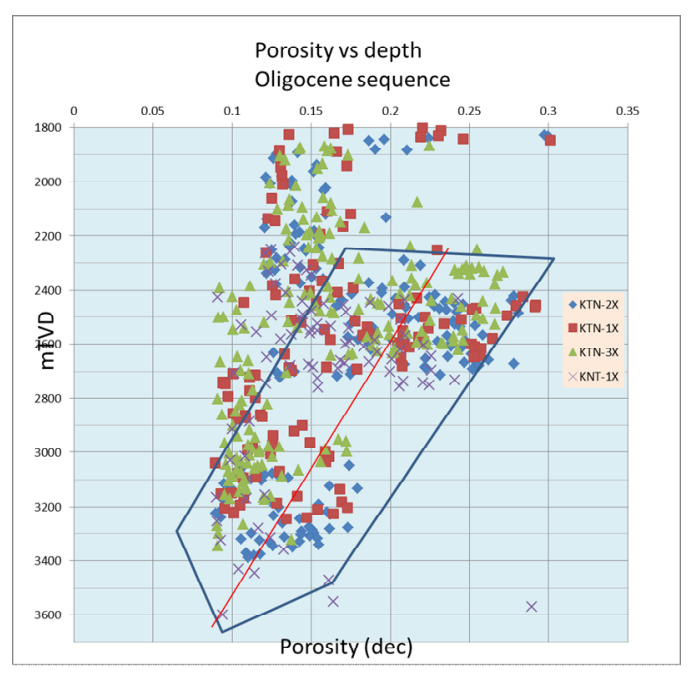

Figure 10. The porosity decreasing versus depth - Oligocene sequence

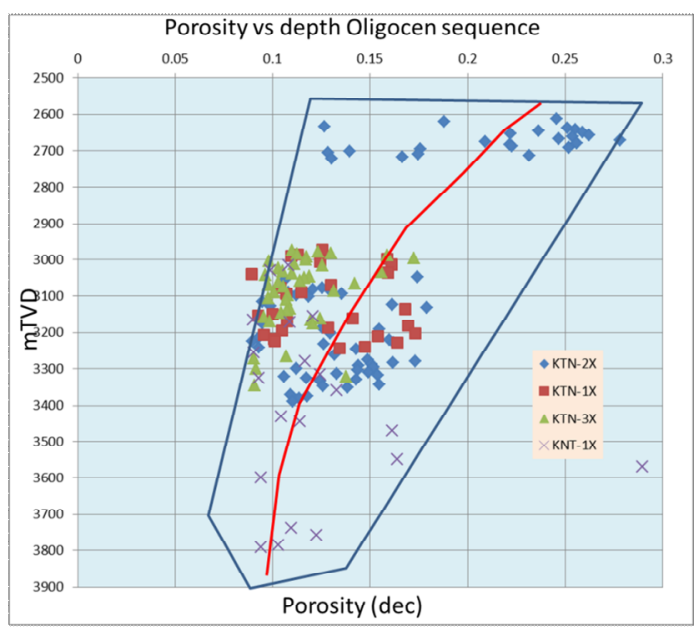

Figure 11. The porosity decreasing versus depth - E sequence
The porosity decreasing versus depth chart indicate the porosity of $\mathrm{E}$ sequence still well until penetrate at depth around 3,900 vertical meter. The effective porosity was preserved around 10 percent at depth 4,000 mTVD.

Equalize of porosity with permeability supported to fair quality of permeability, in the study area, the permeability could up to hundreds $\mathrm{mD} / \mathrm{cP}$ at some wells as figure 12 hereafter.

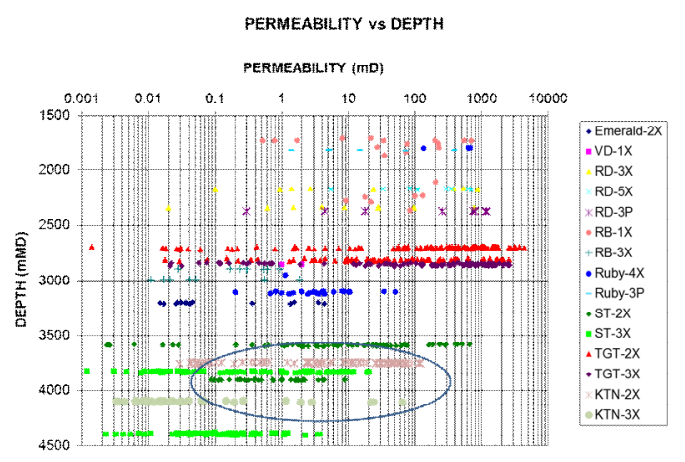

Figure 12. The permeability versus depth relation chart- Oligocene sequence

\section{Conclusions:}

- Before 2005, the exploration results indicated a poor potential in study area except North East part of Bach Ho field; because of low/no nature flow, tiny and regional accumulation.

- Recent exploration achievement illustrated a better potential in Lower Oligocene reservoir in South East margin of Cuu Long basin and many new signs. These new signs need to be highlight researched for predicting accumulation distribution in study area, in purpose of oil and gas exploration for the next step.

- Lithological basement in Southeast margin Cuu Long basin is deeper than acoustic impedance basement; this shows probably "bottom" clastic layers onlap top of granite basement which present in a large area and 
thicker than previous theories. Therefore, oil and gas potential in Lower Oligocene accumulations are also higher.

- Eocene - Oligocene reservoirs in Southeast marginalCuu Long basin preserved porosity - permeability characteristics and probably got oil and gas industry flow in varied sedimentary facies. They distribute in a large area in study area.
- Accumulations in study area distribute widely in Southeast margin Cuu Long basin and probably related to the existence of half-grabens along Con Son swell.

- Mapping of sedimentary facies distribution in purpose of predicting preserved porosity - permeability characteristics accumulations in study area.

\section{Các nhân tố thuận lợi quan trọng biến tập E thành hệ Oligocene trở thành đối tượng dầu khí triển vọng tại khu vực Đông Nam bể Cửu Long}

- Trần Như Huy

Khoa Kỹ thuật Địa chất \& Dầu khí, Trường Đại học Bách Khoa, ĐHQG-HCM \& Cty điều hành thăm dò khai thác dầu khí trong nước

- Trần Văn Xuân

- Nguyễn Xuân Khá

- Thái Bá Ngọc

- Trương Quốc Thanh

- Hồ Nguyễn Trí Mẫn

- Nguyễn Đình Chức

Khoa Kỹ thuật Địa chất \& Dầu khí, Trường Đại học Bách Khoa, ĐHQG-HCM

- Trần Đức Lân

Liên doanh Dầu khí Vietsovpetro 


\section{TÓM TẮT}

Kết quả nghiên cứu truớc đây đều khẳng định tầng chứa cát kết trong Oligocen ha có đặc điểm phân bố phưc tạp, độ rỗng thấm thấp, kết quả thư via tù nhiều giếng không thể hiện khả năng cho dòng tụ nhiên. Trên co sở kết quả nghiên cưu gần đây về môi truờng lắng đọng của tập trầm tích Oligocen ha trong bể Cưu long nói chung và khu vực các lô 01/10 \& 02/10, lô 09-2/09, lô 09-2/10 và lô 16-2 nói riêng, bài báo đã xác định tuớng môi truờng phù hơp với tài liệu vật lý thạch học và tài liệu địa vật lý. Với nguyên lý địa tầng địa chấn, cộng với kết quả minh giải tích hơp tài liệu địa chấn, số liệu giếng khoan, địa vật lý giếng khoan, kết quả

phân tích mẫu lõi-mẫu chất luu, số liệu vật lý thach học và kết quả minh giải thử via, bài báo tập trung xây dựng tuyến liên kết giữa số liệu tù giếng khoan với tài liệu địa chấn nhằm khăng định, làm sáng tỏ sụ phân bố của tập $E$ Oligocen bể Cửu long, lập bản đồ khối môi truoòng lắng đọng trong á nhịp $E$ trên và $E$ duới của Oligocen, thiết lập bản đồ thuộc tính địa chấn của á nhịp E trênvà E dưới trong Oligocen. Cuối cùng dư báo thành công sư phân bố của thân cát trong á nhịp E trênvà $E$ duoói của Oligocen trong khu vục nghiên cưu, tù đó xác định bẫy địa tầng trong thành hệ Oligocen khu vực Đông-nam bể Cửu long.

Tù khóa: Cát kết Oligocen hạ, rỗng-thấm thấp, thuộc tính địa chấn, đuoòng cong vật lý thạch học, đặc trung địa vật lý, dụ báo, phân bố.

\section{REFERENCES}

[1]. PVEP-POC Internal report, 2014;

project "Study of Depositional environment

[2]. Seismic data interpretation, 2014;

[3]. Southeast Asia tectonic model at 10Ma, Robert Hall, 2004; of E Oligocene sedimentary in Cuu Long basin and prediction of $\mathrm{E}$ sand distribution in PVEP POC's area", 2014.

[4]. Tran Van Xuan et al, Final report on 